\title{
PERSEPSI INTRANET E-LEARNING DENGAN GREEN COMPUTING PADA SEKOLAH ADIWIYATA SDN LOWOKWARU 2 MALANG
}

\author{
Suljatmiko \\ STISOSPOL WASKITA DHARMA MALANG \\ Program Studi Ilmu Administrasi Publik \\ E-mail: suljatmiko0775@gmail.com
}

\begin{abstract}
Abstrak : Persepsi intranet e-learning green computing pada sekolah Adiwiyata SDN Lowokwaru 2 Malang. Peradaban dunia semakin modern namun sikap sosial sampai sikap religius semakin terkikis. Intensitas bencana alam yang terjadi di Indonesia adalah hasil dari manajemen lingkungan yang tidak terkontrol. Lembaga pendidikan dasar sebagai konsumsi kertas tidak melakukan kontrol, sehingga menjadi salah satu faktor penyebab terjadinya krisis lingkungan alam Indonesia. Pendidikan lingkungan hidup adalah program modern diharapkan dapat mengembalikan budaya masyarakat cinta dan peduli terhadap lingkungan. Di imlementasikan dari sekolah dasar sampai tingkat atas dalam upaya pelestarian lingkungan alam Indonesia. Program paperless melalui pemanfaatan intranet e-learning green computing sebagai "green technology" menjadi bagian dari solusi yang dapat dikembangkan pada pendidikan dalam menyelamatkan lingkungan dari kerusakan. Intranet e-learning green computing yang joyfull learning, paperless dan full iconic mudah digunakan, hemat energi, serta efektif dan efisien. Intranet $e-$ learning green computing sangat kompeten untuk kegiatan kampanye lingkungan hidup disekolah. Intranet e-learning green computing juga sebagai penghalang (brake tool) terhadap laju degradasi tatakerama. Dengan mempengaruhi penyelenggaran pendidikan untuk paperless maka hutan sebagai produksi utama pembuatan kertas dapat diselamatkan sehingga dapat menciptakan lingkungan hidup Indonesia yang sehat, peduli dan berbudaya lingkungan.
\end{abstract}

Kata Kunci: Intranet, e-learning, green computing, pendidikan, lingkungan, hidup, paperless

\begin{abstract}
Perception of using intranet e-learning green computing for environment education on public elementary school SDN Lowokwaru 2 Kota Malang.

World civilization gets modern but social attitude until religious attitude get to abrade. Happening act of god intensity Indonesian is yielding of environment management that don't be controlled. Elementary of education institute as consumption of paper not does control, so becomes one of its happening causal factor nature environmental crisis Indonesian. Adiwiyata is a environment education that program expected modern get to back society culture loves and care to environmentally. At implementation of elementary school in the effort abiding of environmentally Indonesian nature. Paperless program a benefit Intranet e learning green computing as green technology be part of solution who can be developed on education in saves environmentally of damage. Intranet e learning green computing one that joy full learning, paperless and full iconic edge out to be utilized, low energy, and effective and efficient. Intranet e-learning green computing really competence for environment campaign activity at school. Intranet e learning green computing also as brake tool to fast environment degradation. With regard education institution for paperless therefore forest as production of papermaking main can be saved so gets to create healthy Indonesia environment, care and cultured environmental.
\end{abstract}

Key word: Intranet e-learning green computing, education, environment, paperless

\section{PENDAHULUAN}

Indonesia isu lingkungan adalah masalah yang sangat serius di akhir-akhir ini. Bencana alam yang terus menerus menimpa membuat para pelajar daerah terhalangi dalam memperoleh pendidikan yang layak. Sementara daerah pendidikan yang tidak terkena dampak pada wilayahnya, tidak begitu respon pada permasalahan. Lomba dokumen dan nominasi yang menghabiskan berlembar kertas, pengukuran pembelajaran yang konvensional, menjadi ajang pengerukan hutan Indonesia. Pendapat R.D. Laing, seperti dikutip oleh Fritjof Capra dalam The Web and Life (London,1996), menyatakan bahwa "Kita akan meruksakan dunia ini secara teori sebelum merusakkan secara praktek".

Degradasi tata kerama yang berakibat krisis moral sampai pada krisis lingkungan hidup lingkungan alam Indonesia. Alam Indonesia akan menjadi porak-poranda jika kehidupan masyarakat yang konsumtif tanpa mempertimbangkan caring capacity terhadap lingkungan itu sendiri. Modal usaha yang paling utama adalah penanaman tatakrama lingkungan dari tingkat sekolah dasar sampai tingkat lanjut harus disampaikan secara mendalam oleh penyelenggara pendidikan.

Pendidikan Lingkungan Hidup (Adiwiyata) sebagai media yang sangat kompeten diharapkan 
dapat bekerja sama secara sinergi dengan pemangku kepentingan dalam mentransfer budaya demi menyelamatkan lingkungan Indonesia dari bencana alam serta sebagai pendukung utama dalam melestarikan alam Indonesia. Adiwiyata bukanlah sebuah ajang lomba pamer fisik bentuk dokumen, bangunan dan rindangnya pepohonan disekolah.

Esensi adiwiyata adalah membangun karakter budaya bangsa Indonesia dalam misi menyelamatkan Indonesia dari degradasi tatakerama dan krisis lingkungan alam.

Intranet e-learning green computing sebagai green technology adalah media pembelajaran yang joy full learning, paperless dan full iconic, hemat energi serta ramah terhadap lingkungan.

Melalui provokasi kepada seluruh penyelenggara pendidikan untuk melakukan pengukuran berbantu intranet e-learning green computing diharapkan dapat paperless, hemat energi listrik sehingga gagasan untuk mencapai tujuan pendidikan lingkungan hidup dalam upaya menyelamatkan dan melestarikan alam Indonesia dapat berjalan.

Dukungan dari pemangku kepentingan sampai pada seluruh pemerhati lingkungan hidup sangatlah dibutuhkan dalam mengimplementasi dan mengaplikasi program intranet e-learning green computing sehingga dapat memenuhi aspek yang tetuang dalam Peraturan Menteri Lingkungan Hidup No. 5 Tahun 2013 tentang Pedoman Pelaksanaan Program Adiwiyata.

\section{TINJAUAN PUSTAKA}

\section{Pembangunan berkelanjutan}

Menurut Emil Salim (1986:h.34) bahwa "pemilihan teknologi dalam ilmu pengetahuan yang tepat sangat membantu usaha mencegah kerusakan lingkungan. Hal ini memerlukan "penglihatan lingkungan" (environmental vision) yang sudah tertanam berkat hasil pendidikan. Karena itu sejak tingkat Sekolah Dasar hingga perguruan tinggi, baik dibidang pendidikan kokurikuler sampai pendidikan ekstrakurikuler, sangatlah utama pada penglihatan lingkungan ini diaplikasikan. Inti aplikasi lingkungan adalah memahami hubungan saling kait mengkait (interdependensi) antara mata rantai yang satu dengan yang lain dalam siklus kehidupan ekosistem.

\section{Isu Global dan Masalah Lingkungan}

Secara umum global data menunjukkan bahwa bencana alam akan sering muncul jika tidak dihentikan. Untuk menghambat akumulasi gas rumah kaca, emisi global harus minimalisasi. Pemakainan energi listrik yang berlebihan adalah penyebab utama perubahan iklim, batubara atau minyak yang membantu menghasilkan listrik juga melepaskan karbon dioksida, polutan, dan sulfur ke atmosfer. Emisi ini dapat menyebabkan penyakit pernafasan, asap, hujan asam, dan perubahan iklim global. Mengurangi konsumsi listrik adalah kunci untuk mengurangi emisi karbon dioksida yang berdampak pada lingkungan. (Murgen, 2008: $h .25$ )

\section{Konsep Pendidikan Lingkungan Hidup (PLH)} Kehadiran manusia yang telalu serakah inilah yang menyebabkan terjadinya krisis lingkungan, hal ini senada dikatakan Siahaan dalam hukum lingkungan hidup Siahaan (2004: h.2) bahwa, "persoalan-persoalan lingkungan saat ini, seperti pencemaran kerusakan sumber daya alam, penyusutan cadangan-cadangan hutan, musnahnya berbagai jenis spesies hayati, tanah longsor, banjir bandang, bahkan berkembangnya wabah penyakit yang terjadi diterakhir ini, merupakan gejala-gejala negatif yang secara sadar bersumber dari faktor manusia itu sendiri".

Menurut Sudjoko (2011: h.2.13) dalam PLH menjelaskan tentang manusia, sumber daya alam dan pengelolaan sumber daya alam, bahwa ilmu pengetahuan dan teknologi yang berhasil kita temukan tidak dapat memisahkan kita dari keterbatasan daya dukung lingkungan, dimana sumber daya alam hanya cukup untuk ada, tetapi pelum tentu berlanjut keberadaanya.

Peraturan Menteri Lingkungan Hidup No. 5 Tahun 2013 tentang Pedoman Pelaksanaan Program Adiwiyata yang menetapkan komponen pelaksanaan Adiwiyata yaitu: 1.) aspek kebijakan sekolah yang berwawasan lingkungan; 2.) aspek kurikulum sekolah berbasis lingkungan; 3.) aspek kegiatan sekolah berbasis partisipatif; dan 4.) aspek pengelolaan sarana dan prasarana pendukung sekolah yang ramah lingkungan.

\section{Intranet E-learning}

Intranet adalah teknologi jaringan komputer yang menguhungan antara komputer induk (server) dengan clent yang dibangun dalam lingkup scope kecil (local). Teknologi intranet menyerupai internet yang menggunakan TCP/IP 
dalam koneksitas antar server dan client. Teknologi intranet dapat dikembangkan dengan teknologi jaringan nirkabel yang dapat diakses dengan menggunakan Tab atau HP yang didukung dengan Operating System (OS) berbasis android.

Berbantu software Xampp (local server) dan menggunakan platform yang mudah digunakan sekaligus mendukung Operating System (OS) berbasis Windows yaitu Modular Object Oriented Learning Dynamic Environment (Moodle) dapat diperoleh secara gratis dan mudah untuk dikembangkan sebagai media pembelajaran yang terintergrasi dengan lingkungan hidup. Terutama digunakan pada kalangan pendidikan lingkungan hidup.

Menurut Sudjoko (2011:h.123) untuk mengembangkan metode pelaksanaan Pendidikan Lingkungan Hidup (PLH) penamfaatan teknologi terus menus diupayakan sehingga pengembangan pendidikan lingkungan hidup dapat berhasil.

Menurut Arsyad Azhar (2011:h.15-27) dalam fungsi media pendidikan adalah afektif, kognitif, kompensatoris. Sedangkan manfaat pendidikan. adalah memudahkan guru mengetahui sejauh mana siswa berhasil dalam belajar Jaringan intranet sangat sesuai di install jenjang pendidikan dasar (SD) . Keuntungan jaringan intranet adalah investasi sangat rendah.

\section{Green Computing}

Menurut Anggeriana (2011:h.12) bahwa mannfaat dan tujuan cloud computing adalah menudukung program go green.

Menurut Murugesan (2008:h.25-26), green IT adalah "studi dan hasil dari perakitan, penggunaan, dan emisi komputer, server, serta subsistem seperti pranata input, pranata penyimpanan, serta teknologi jaringan dan sistem komunikasi secara efisien dan efektif dengan pengaruh minimal atau bahkan tidak berdampak terhadap lingkungan alam".

Thin Client adalah hardware pengganti unit CPU yang diciptakan untuk mengatasi isu global warming sehingga menjadi hardware dengan teknologi ramah lingkungan. Dengan mempertimbangkan spesifikasi dan kecepatan sehingga dapat mendukung Operating System (OS) berbasis close source, seperti Windows XP, Window 7 dan open source seperti linux. Dengan hardware yang sangat praktis, green computing sangat mudah di install dan dapat diletakkan dibelakang monitor sehingga performanya praktis.
Green Computing sangat sesuai digunakan baik pada sekolah yang menerapkan pendidikan lingkungan hidup ataupun yang belum. Adapun keuntungan menggunakan green computing diantaranya diantaranya: design ramah lingkungan, hemat energi listrik, tidak bising, emisi karbon rendah dan investasi rendah (Sunde Indonesia, 2016)

\section{METODE}

Menurut Sugiyono (2007:1) penelitian kualitatif adalah penelitian alamiah (natural setting), sesuai pada penelitian bidang antropologi budaya. Penelitian ini untuk mendapat gambaran persepsi penggunaan intranet e-learning green computing penelitian ini menggunakan teknik pendekatan kualitataif. Hakekat penelitian ini adalah mengamati perilaku warga sekolah yang menggunakan intranet e-learning green computing. Dengan teknik pendekatan kualitatif, data yang diperoleh akan lengkap, mendalam, kredibel dan bermakna. Dengan teknik ini dapat menggali fakta yang bersifat empirik dan terukur. Pada fakta yang sulit diungkap, data diperoleh secara konsisten sampai jenuh, sehingga kredibilitas data semakin tinggi.

Fokus dari penelitian ini adalah: 1) Persepsi user terhadap penggunaan intranet e-learning dengan green computing dari: a. Persepsi pendidik b. Persepsi tenaga kependidikan c. Persepsi peserta didik; 2) Faktor-faktor yang mendukung dan penghambat dalam menggunakan intranet $e$ learning green computing dari: a. Pranata Intranet elearning green computing b. Anggaran Sekolah. c. Kemitraan d. Budaya peduli lingkungan; 3) Model pembelajaran yang sesuai pada sekolah Adiwiyata dari a. Kebijakan sekolah berwawasan lingkungan. b. Kegiatan sekolah berbasis Lingkungan Hidup (LH).

Lokasi penelitian ini di sekolah yang sudah menerapkan program Adiwiyata situs penelitian pada SDN Lowokwaru 2 Kota Malang. Sumber data dari informan, observasi dan dokumentasi.

Menurut Indrajid (2006:25) bahwa "pada lingkungan ini, setiap individu dapat berhubungan dengan siapa saja secara one-on-one, namun tetap efektif dan efisien". Teknik pengumpulan data dengan cara wawancara mendalam melalui kuesioner yang dimodifikasi melalui online intranet lokal sekolah yang dapat dijawab melalui Laptop, Tab atau HP berbasis android, pengamatan konsisten dan dokumentasi. Peneliti menjadi instrument, catatan lapang dan pedoman wawancara. Keabsahan data dalam penelitian ini menggunakan 
uji kredibilitas, seperti yang dijelaskan (Sugiyono, 2007:h.121) bahwa uji kredibilitas atau kepercayaan dari data hasil penelitian kualitatif antara lain dilakukan dengan perpanjangan pengamatan, optimal dan tekunan dalam proses triangulasi, diskusi dengan sejawat, analisis kasus negatif, dan check member. Analisisa data menggunakan analisis interaktif model Miles and Huberman (2014:14) yaitu data condensation, data display dan verification.

\section{PEMBAHASAN}

1. Persepsi user terhadap penggunaan intranet $e$ learning green computing pada sekolah Adiwiyata.

\section{A. Persepsi Tenaga Kependidikan,}

a.) Intranet e-learning green computing dinyatakan sebagai "green technology".

Menurut Sudjoko (2012:h.122) bahwa "meningkatkan informasi yang bekualitas, pemanfaatan teknologi perlu terus diupayakan sehingga pengembangan pendidikan lingkungan dapat berhasil serta sekaligus memberikan akses bagi masyarakat tentang pendidikan lingkungan hidup". Pada SDN Lowokwaru 2 seluruh tenaga pendidik menyatakan bahwa intranet e-learning green computing penting dalam mendukung program Adiwiyata dengan alasan bahwa hemat energi listrik, hemat kertas dan efektif efisien. Alasan lain bahwa intranet e-learning green computing dapat dijadikan sebagai pengembangan diri.

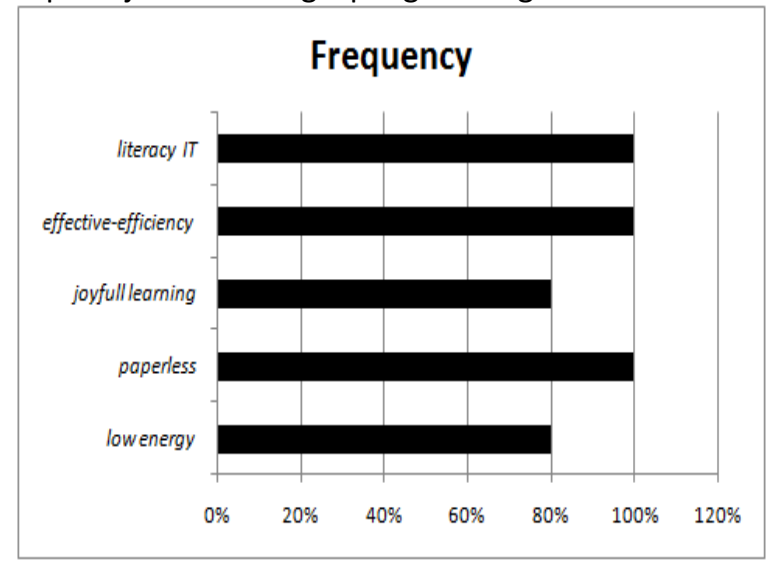

Gambar 1. Persepsi intranet e-learning green computing

b.) Intranet e-learning green computing dinyatakan sebagai media inovatif dan edukatif.

Menurut Arsyad Azhar (2011:h.55) bahwa kemampuan merekam aktivitas siswa menggunakan suatu program pembelajaran memberi kesempatan lebih baik untuk pembelajaran secara perorangan dan perkembangan setiap siswa selalu dipantau. Tenaga Pendidik di SDN Lowokwaru 2, frekuensi persepsi yang diperoleh ada 80 persen tenaga pendidik menyatakan bahwa persepsi menggunakan intranet e-learning green computing menyenangkan karena pendidik langsung memperoleh hasil yang diukur dan langsung mengetahui siapa peserta didik yang belum tuntas, dan langsung memberikan remedial. Alasan lain karena dalam melakukan penilaian soal yang bergambar (iconic) tampak seperti warna sebenarnya. Sisanya 20 persen menyatakan tidak senang karena tidak menguasai peralatan TIK.

c.) Intranet e-learning green computing, dinyatakan sebagai media penghalang (brake tool) degradasi tatakerama peserta didik.

Menurut Arsyad Azhar (2011:h.23) yang mengemukakan bahwa manfaat media pembelajaran salah satunya adalah "peran tenaga pendidik bisa berganti kearah positif yang lebih fokus pada aspek membangun karakter seperti konsultan dan penasihat siswa." Pendidik di SDN Lowokwaru 2 dalam peng-administrasian model konvensional yang mulai ditinggalkan. Peng-administrasian model konvensional yang mulai ditinggalkan karena karena berbentuk file. Pendidik mempunyai banyak waktu mengembangkan karakter yang berbudi pekerti luhur, berintegritas tinggi, peduli dan berbudaya lingkungan.

\section{B. Persepsi Tenaga Kependidikan}

Menurut Sudjoko (2012:h.121) bahwa untuk meningkatkan kualitas dan kemampuan (kompetensi) komponen PLH, baik penyelenggara maupun tujuan sasaran PLH sedini mungkin melalui berbagai upaya proaktif dan reaktif dengan meningkatkan kemampuan SDM dibidang Lingkungan Hidup dalam profesionalitas (kompetensi) tenaga kependidikan. Pada tenaga kependidikan di SDN Lowokwaru 2 dalam penggunaan intranet e-learning green computing menyatakan cukup senang. Hal ini disampaikan dalam pernyataannya bahwa dengan munggunakan aplikasi tersebut hasil evaluasi yang disetor ke Bag. Administrasi sudah berbentuk file dan bukan lagi yang tertuang dalam daftar di kertas. Jika membutuhkan nilai secara mendadak dapat secara cepat diunduh pada komputer server.

\section{Persepsi Peserta Didik}


a.) Intranet e-learning green computing, dinyatakan sebagai solusi isu lokal (local issue).

Menurut Sudjoko (2012:h.122) untuk materi PLH yang berbasis isu lokal, modern disesuaikan pada kelompok sasaran, dalam hal ini adalah peserta didik. Pada SDN Lowokwaru 2 para peserta didik, mereka menyatakan penggunaan intranet e-learning green computing sangat sesuai diaplikasikan di sekolah Adiwiyata, karena pengukuran yang paperless sehingga mengurangi sampah kertas.

b.) Intranet e-learning green computing dinyatakan sebagai media yang joyful learning berbasis gambar (iconic).

Menurut Sudjoko (2012:h.123) bahwa metode pelaksanaan pendidikan lingkungan adalah hal yang sangat berperan dalam menghasilkan proses pembelajaran yang berkualitas yaitu dengan joyful learning process. Sedangkan menurut Arsyad Azhar (2011:h.55) bahwa alat bantu komputer bisa memotivasi siswa untuk melakukan latihan, melakukan kegiatan praktikum di laboratorium atau simulasi karena terfasilitasinya animasi grafik, warna dan musik yang dapat merangsang dan merealisasikan. Di SDN Lowokwaru 2 penggunaan intranet e-learning green computing menunjukkan bahwa tingkat kemudahan dan menyenangkan sebanyak 95,68\% menyatakan mudah dan menyenangkan. Dari 96,36\% memilih senang dikarenakan cepat mengetahui hasil yang dikerjakan, ada juga yang menyatakan bahwa mengerjakan tidak menggunakan peralatan tulis dan ingin cepat bermain. Sedangkan sebanyak 3,18\% menyatakan tidak senang. Dari 3,18\% menyatakan tidak senang karena waktu ada batasan waktu mengerjakan, ada juga yang beralasan bahwa setiap membuka programnya soalnya teracak (random). Karena setiap membuka soal yang keluar berbeda. Sebanyak 0,45\% tidak dianggap tidak tahun karena karena siswa kehabisan batas waktu dalam menjawab wawancara. Ini dikarenakan peserta didik dalam melakukan pengukuran pada pelajaran TIK sudah terbiasa dengan model quiz yang sudah diterapkan pada pembelajaran TIK.

c.) Intranet e-learning green computing, dinyatakan sebagai media pembangkit PLH

Menurut Arsyad Azhar dalam Ibrahim (196: h.432) bahwa media pembelajaran membawa dan membagkitkan rasa senang dan memperharui semangat. Arsyad Azhar (2011:h.169) juga menjelaskan bahwa siswa harus merasakan bahwa keberhasilan itu menyenangkan dan menguntungkan dengan demikian siswa menjadi akan termotivasi. Pada peserta didik SDN Lowokwaru 2 hasil capaian ketuntasan minimal pada akhir pembelajaran dalam menggunakan intranet e-learning green computing sangat memuaskan, sehingga menginginkan bidang studi yang lain mengikuti penilaian yang paperless.

Frekuensi olahan data yang diambil didalam program tersebut mengetahui bahwa 95,45\% peserta didik menyatakan puas dari hasil yang diperoleh. Hal ini dikarenakan kesiapan materi selebum dilakukan evaluasi. Untuk sisanya 4,09\% menyatakan tidak puas dikarenakan kurang ketertarikan dalam menggunakan intranet e-learning green computing, ini disebabkan karena peserta didik sendiri tidak belajar selum dilakukan pengukuran. Sebanyak 0,45\% tidak dianggap tidak tahu karena siswa kehabisan batas waktu dalam menjawab wawancara.

\section{Faktor-faktor yang mendukung dan penghambat dalam menggunakan intranet e-learning green computing.}

\section{A. Pranata Intranet e-learning green computing}

Menurut Sudjoko (2012:h.121) bahwa dengan mengoptimalkan sarana dan prasarana PLH yang dapat mendukung terciptanya proses pembelajaran yang efisien dan efektif dengan menggunakan perpustakaan, laboratorium, alat peraga alam sekitar dan sarana lain sebagai sumber pengetahuan". Menurut Arsyad Azhar (2011:h.54) bahwa "kekuatan dan keterbatasan komputer yang digunakan untuk tujuan pendidikan".

Faktor pendukung, antara lain 1.) Pranata yang digunakan adalah PC station $\mathrm{H} 4$ dengan teknologi yang mendukung aplikasi mulai dari windows XP sampai Win7; 2.) Dalam 1 Lab. TIK ada 20 user maka, konsumsi listrik pengganti CPU yang dibutuhkan hanya 75 watt; 3.) Bentuknya yang sangat praktis, sehingga dalam tata letak mudah untuk menempatkannya; 4.) Hanya 2 operating system (OS) yang resmi (legal license) dibutuhkan untuk satu laboratorium komputer; (5) Ramah terhadap lingkungan, karena tidak menimbulkan suara bising dan tidak mengeluarkan emisi $\mathrm{CO}^{2}$

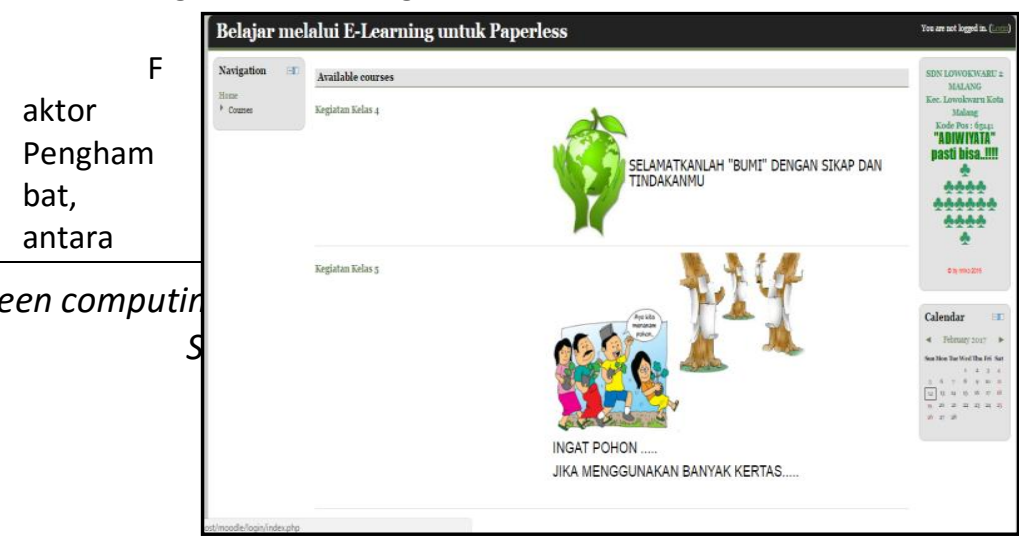


lain: 1.) Hanya didesign dengan menggunakan Kabel LAN model straight dan cross over, tidak didukung jaringan nirkabel; 2.) Untuk menghubungkan ke HP atau laptop menambah pranata Access Point (AP); 3.) Topologi client server remote desktop akan menghambat jika salah satu server terjadi trouble maka client tidak dapat digunakan.

\section{B. Anggaran Sekolah}

Menurut Sudjoko (2012:h.121) bahwa untuk meningkatkan dan memanfaatkan anggaran PLH dan mendorong partisipasi publik serta meningkatkan kerjasama regional, internasional untuk penggalangan dana PLH. Sesuai petunjuk teknis penggunaan dana BOS 2016 anggaran pengadaan aset sekolah keseluruhan hanya $20 \%$. SDN Lowokwaru 2 perawatan dan pengadaan aset Lab. TIK tidak mempunyai anggran rutin sekolah, ini mengakibatkan jika terjadi truble maka proses pengukuran kembali pada konvensional.

\section{Kemitraan}

Menurut Sudjoko (2012:h.122) kerjasama dibutuhkan guna mendorong ketersediaan ruang partisipasi bagi masyarakat dalam penyelenggaraan dan pengendalian mutu pelayanan PLH meliputi peran serta perseorangan, keluarga, organisasi profesi, pengusaha dan organisasi kemasyarakatan dalam sistim pengendalian mutu pendidikan perlu terus digalakkan (Pasal 54, UU Sisdiknas 2003).

Faktor pendukung, Di SDN Lowokwaru 2 dana pengembangan intranet e-learning green computing berasal bantuan dari donatur berupa pranata dari para alumni dan wali siswa yang peduli terhadap sekolahnya. Kerjasama lain bidang pengembangan pembelajaran dengan sekolah rujukan. Sedangkan faktor penghambat, belum terjalinnya kerjasama secara sinergi antara dengan perguruan tinggi setempat, Sekolah Menengah Kejuruan (SMK) pada keahlian Teknisi Komputer dan Jaringan (TKJ), dalam meningkatkan kompetensi bidang TIK.
Gambar 2. Kampanye peduli lingkungan melalui intranet

\section{Budaya peduli lingkungan}

Menurut Sudjoko (2012:h.121) bahwa pembudayaan nilai sikap dan kemampuan dengan membangun komitmen bersama untuk PLH dan mendorong terbentuknya sistem monitoring dan evaluasi pelaksanaan PLH. Di SDN Lowokwaru 2 budaya tanggap terhadap lingkungan masih tertuju pada kegiatan-kegiatan yang bersifat penghijauan saja seperti menanam bunga hias, tanaman toga serta pemeliharaan terhadap pepohonan yang ada di sekolah. Budaya melek teknologi yang dapat memaksa para tenaga pedidik untuk menerapkan budaya paperless masih sangat minim.

\section{Pengembangan Model pembelajaran yang sesuai pada sekolah Adiwiyata}

A. Kebijakan Sekolah Berwawasan Lingkungan

Menurut Sudjoko (2012:121) meningkatkan kapasitas kelembagaan PLH sebagai pusat pembudayaan nilai, sikap dan kemampuan dalam pelaksanaan PLH dengan mendorong tersusunnya kebijakan PLH. Pada SDN Lowokwaru 2 Malang sudah menerapkan kebijakan berwawasan lingkungan yang tertuang dalam kurikulum yang diimplementasikan pada Rencana Pokok Pembelajaran (RPP), kebijakan-kebijakan lain seperti penetapan tim pokja Adiwiyata, kampanyekampanye dalam mensukseskan program adiwiyata melalui media elektronik dan media cetak.

Belum ada kebijakan khusus tentang penggunaan intranet e-learning sekolah terkait dalam pengukuran pembelajaran baik pada pelajaran tematik maupun bidang studi.

Ini disebabkan karena penyelenggara, belum mengoptimalkan inovasi sarana dan prasarana sekolah dalam Lab. Komputer.

B. Kegiatan sekolah berbasis Lingkungan Hidup (LH) Menurut Sudjoko (2012:h.123) bahwa dalam mengembangkan materi PLH yang berwawasan pembangunan berkelanjutan, komprehensif dan aplikatif dengan mengintegrasikan pengetahuan lingkungan yang berwawasan pembangunan berkelanjutan.

Kegiatan Lingkungan Hidup (LH) di SDN Lowokwaru 2 Malang, masih bersifat pemenuhan 
kebutuhan penilaian dalam lomba Adiwiyata, bukan pembiasaan atau budaya menuju peduli lingkungan. Melalui intranet e-learning green computing penanaman karakter peduli lingkungan dapat dibuat secara online sekolah saat menggunakan media.

\section{KESIMPULAN}

Intranet e-learning green computing sebagai "Green Technology", sangat penting untuk aplikasikan pada sekolah adiwiyata. Karena dapat dijadikan sebagai produk sekolah unggulan dalam menginovasi sarana dan prasarana pendukung Adiwiyata. Sangat mudah digunakan dan menyenangkan bagi para peserta didik, tenaga pendidik dan peserta didik. Dengan intranet e-learning green computing dapat menyeimbangkan pemakaian kertas (paperless), pengelolaan administrasi menjadi lebih tertib, efektif dan efisien, hemat anggaran sekolah dan energy listrik karena daya listrik untuk satu hardware hanya 5 watt. Dengan teknologi client-server, platform yang digunakan moodle dan xampp dapat diperoleh secara gratis. Penyelenggara pendidikan hanya membeli oprating system (OS) Windows secara legal sejumlah server saja. Sangat praktis pada tata letak pranata sehingga user lebih nyaman, tidak bising, tidak mengeluarkan emisi $\mathrm{CO}^{2}$ dan ramah lingkungan. Dapat dimodifikasi sesuai kebutuhan pelajaran sekolah guna penyampaian materi yang bersifat teoritis, pengukuran dan pesan dan atau slogan tentang peduli dan berbudaya lingkungan. Mengerjakan quiz pada intranet e-learning green computing pada pelajaran berhitung, peserta didik pesimis dalam menjawab, mengingat tidak memanfaatkan lembar buram, karena ada batasan waktu. Namun intranet e-learning green computing tidak dapat digunakan jika tidak ada sumber listrik. Diperlukan penguasaan TIK mendalam jika terjadi trouble shoting.

\section{SARAN}

Dibutuhkan intervensi penyelenggara dalam pemenuhan kebijakan melalui literasi TIK, agar dapat membuat intranet e-learning green computing pada perangkat TIK yang dimiliki para pendidik, sehingga dapat lebih mendalam, dalam memenuhi kebutuhan adaministrasi dan memberikan hak peserta didik dalam memperoleh petuah teladan sekaligus berbudaya lingkungan. Perlunya menjalin kerjasama sinergi antara penyelenggara sekolah dengan Perguruan Tinggi sekolah, bahkan Sekolah
Menengah Kejuruan (SMK) terutama pada kelahlian Teknik Komputer dan Jaringan, sehingga terjadi sismbiosis muatualisme, pihak sekolah diuntungkan dengan perawatan dan pengetahuan sekolah secara sistemis dan gratis, sedangkan pihak SMK keahlian TKJ atau jenjang pendidikan tinggi dapat memperoleh tempat magang sehingga tersalukan dalam memperdalam keahlian pada Pendidikan Sistem Ganda (PSG) atau Praktikum Kerja Lapang (PKL). Tetap menambah wawasan dan pengetahuan bagi guru di bidang TIK melalui memperdalam pengetahuan secara mandiri, seminar, workshop atau pelatihan-pelatihan. Intranet e-learning green computing, dapat dijadikan kegiatan utama yang dapat mengimbangi kebutuhan sekolah pada jenjang yang lebih tinggi, kedepan pemerintah melalui Kementrian Pendidikan dan Kebudayaan akan menganjurkan seluruh sekolah mulai dari SMP sampai SMA di Indonesia menganjurkan menggunakan ujian online. Pembudayaan sikap dan perilaku peduli dan cinta terhadap lingkungan alam Indonesia dengan melalui gerakan paperless

\section{TERIMA KASIH KEPADA}

Dengan selesainya penelitian ini, penulis mengucapkan terima kasih kepada semua pihak yang telah membantu dan mendukung baik secara substansi maupun finansial sehingga penelitian dengan judul Persepsi intranet $e$ learning green computing pada sekolah Adiwiyata SDN Lowokwaru 2 Malang dapat terselesaikan.

\section{DAFTAR PUSTAKA}

Anggeriana , Herwin, 2011. "Cloud Computing", http://www.facebook.com/ITlinks.co.id $[18 / 02 / 2017)$

Arsyad, Azhar, 2011. "Media Pembelajaran". Jakarta : PT. Raja Grafindo Persada.

Eko, Indrajid, Richardus, 2006. "Electronic Gouvernment: Konsep Pelayanan Publik Berbasis Internet dan Teknologi Informasi". Jakarta : Aptikom, 2006

Miles, Matthew B dan Huberman, Maichael A. (2014) “Qualitative Data Analysis". United States of America. Sage Publications.

Kementerian Lingkungan Hidup, 2011, "Teologi Lingkungan: Etika Pengelolaan Lingkungan dalam Perspektif Islam" Jakarta : Deputi Komunikasi Lingkungan dan Pemberdayaan 
Masyarakat, KLH, Dan Majelis Lingkungan Hidup Pimpinan Pusat Muhammadiyah, 2011

Peraturan Menteri Lingkungan Hidup Republik Indonesia Nomor 05 Tahun 2013 tentang Pedoman Pelaksanaan Program Adiwiyata

Prasetyo, Hazairin Eko. "Indonesian Paperless Education: An Integrated Strategy for A More Sustainable Development."

Salim, Emil, 1986. "Pembangunan Berwawasan Lingkungan". Jakarta : LP3ES

San Murugesan, 2008. "Harnessing Green IT: Principles and Practices," IEEEIT Professional, January-February 2008, pp 24-33

Sudjoko at.al., 2012. "Pendidikan Lingkungan Hidup", Tangerang Selatan: Universitas Terbuka

Siahaan, N.H.T, 2004. "Hukum Lingkungan Dan Ekologi Pembangunan". Jakarta : Erlangga

Sunde Indonesia, 2016. "Green Computing

Environment". melalui http://www.sundeindonesia.com/?module=a bout\&ID3 [11/11/16]

Yao, Tung, Khoe, 2001. "Teknologi Jaringan Intranet", Yogyakarta : Andi

http://id.wikipedia.org, [18/02/2017] 